Dhaka Univ. J. Biol. Sci. 19(2): 151-155, 2010 (July)

\title{
MUTATION IN NEUROSPORA CRASSA WITH LEAF EXTRACT OF CITRUS AURANTIFOLIA AND THEIR SOLUBLE PROTEIN CONTENT
}

\author{
Apurba Lal Ray ${ }^{1}$, Mahbuba Akhter Jahan and Tahsina Rahim \\ Department of Botany, University of Dhaka, Dhaka-1000, Bangladesh
}

Key words: Neurospora crassa, Mutation, Leaf extract, Soluble protein

\begin{abstract}
Leaf extract of Citrus aurantifolia exhibited remarkable inhibitor effect on the radial mycelial growth of Neurospora crassa. The extract also showed mutagenic effect and atleast six morphological mutants of the fungus were detected including albino (al 243), vigorous (vg 117), fluffy (fl 220), colonial (cl 232), conidial band (con. band 171) and dirty (dir 83). The mutants were used for estimation of soluble protein in comparison with the wild type (Ema). The soluble protein content increased to some extent in case of the mutants con. band $171(192.86 \mu \mathrm{g} / \mathrm{ml}), \mathrm{cl} 232(188.57 \mu \mathrm{g} / \mathrm{ml})$ and $\mathrm{vg} 117(186.43 \mu \mathrm{g} / \mathrm{ml})$ as compared to the wild type $(182.14 \mu \mathrm{g} / \mathrm{ml})$. On the other hand, the soluble protein content was remarkably decreased in case of the mutant al $243(94.28 \mu \mathrm{g} / \mathrm{ml})$, which was about $50 \%$ less than the control. This indicates that the leaf extract not only effect colony morphology but possesses profound effect on growth and metabolism of the fungus.
\end{abstract}

\section{Introduction}

Neurospora crassa is a nonpathogenic filamentous fungus of the class Ascomycetes. Edward Tatum and George Wells Beadle exposed N. crassa to x-rays, causing mutations. They then observed failures in metabolic pathways. In many organisms, mutation produces different genotypes and those differences can result in different phenotypes. Many mutations have little effect on an organism's phenotype and metabolism.

Neurospora crassa is used as a model organism because it is easy to grow and has a haploid life cycle. No evidence has been obtained that Neurospora is the causal agent of any disease or infection. (1) On the other hand, proteins are essential parts of organisms and participate in every process within cells. Proteins are the chief actors within the cell, said to be carrying out the duties specified by the information encoded in genes.(2) Proteins make up half the dry weight of an Escherichia coli cell, whereas other macromolecules such as DNA and RNA make up only 3 and $20 \%$, respectively.(3) For this reason, the study of protein content is important. This knowledge is helpful to know the amount of protein in the mutants in comparison with the wild type. Besides, many researchers used plant extracts for the study of antifungal activity ${ }^{(4,5)}$ and induction of mutation.(6,7) In this study, leaf extract of Citrus aurantifolia (Chist) SW was used as natural chemical mutagen for induction of mutation in N. crassa. The mutants were then used for estimation of water soluble protein.

${ }^{1}$ Corresponding author: E-mail: apurba.anirban@gmail.com 


\section{Materials and Methods}

Mutation in Neurospora crassa (Ema, 5297) was induced by using leaf extract of Citrus aurantifolia (Chist) SW. The wild type isolate of $N$. crassa was obtained from Microbial Genetics Stock, Department. of Botany, University of Dhaka, Dhaka. Vogel's minimal medium ${ }^{(8)}$ was used for culturing $N$. crassa in the test tube and also to study the mutagenic effect on culture plate. Sorbose minimal medium (SM) was used for single colony isolation. To test mutagenic effect of Citrus aurantifolia leaf extract on the growth of $N$. crassa, different concentrations of the extract was prepared with sterilized distilled water. Fungal growth was determined by measuring the radial growth of mycelia of Ema up to $30 \mathrm{hr}$. For mutation in N. crassa, $4 \mathrm{ml}$ of C. aurantifolia leaf extract was taken into a centrifuge tube and one loop of conidia of Ema was added to it and shaken for homogenous suspension. The tube was kept for $2 \mathrm{hr}$ for mutation and thereafter the suspension was centrifuged and the supernatant above conidia was poured out from the centrifuge tube. The conidial plate was re-suspended with $4 \mathrm{ml}$ of sterile distilled water and centrifuged for 5 minutes. The same procedure was repeated three times. Finally treated conidia were suspended in $1 \mathrm{ml}$ of sterilized distilled water and used as inoculum. One drop of the conidial suspension was mixed with $10 \mathrm{ml}$ of molten SM medium in sterilized Petri dish. The Petri dishes were kept inside the incubator at $25^{\circ} \mathrm{C}$ for $24 \mathrm{hr}$ for growth. Well separated colonies were isolated from each Petri dish by cutting agar blocks from the fungal colonies and were inoculated into small tubes containing VM medium. After five days, all the cultures were observed and classified by comparing their characters with wild type Ema.

For estimation of soluble protein content of wild and mutants of $N$. crassa (Ema), the organisms were grown in VM liquid medium $(100 \mathrm{ml})$ in conical flask for up to $72 \mathrm{hr}$. After incubation, the cultures were filtered and dried. Dry mycelia of the organisms were crushed with mortar and pastle within ice box. Before that, liquid nitrogen was used to breakdown the cell wall of the organisms. The fine crushed mycelia were taken in Eppendorf tube and centrifuged at 13,000 rpm for 10 minutes to remove cell debris. The supernatant of the samples was taken for estimation of soluble protein by the method of Lowry et al. using bovine serum albumin (BSA) as standard.(9) In each case, $20 \mu \mathrm{l}$ of sample (supernatant) was taken with $980 \mu \mathrm{l}$ of sterilized distilled water (total volume 1 $\mathrm{ml}$ ) for estimation of soluble protein.

\section{Results and Discussion}

Citrus aurantifolia (Chist) SW is a medicinal plant and its leaf contains essential oil. Psoralens and substituted coumarins are present in the oil.(10) Leaf extract of $C$. aurantifolia showed considerable growth inhibitory mutagenic effects on $N$. crassa. The growth inhibitory effect was evaluated by measuring the radial growth of mycelia of the fungal strain Ema on VM agar plates. It was found that growth inhibitory effect increased with 
the increase of leaf extract concentration in VM medium (Table 1). Lower radial growth was also corresponded to higher mutagenic effect.

Table 1. Radial mycelial growth of Neurospora crassa (Ema) on VM agar plates containing leaf extract of Citrus aurantifolia.

\begin{tabular}{ccccc}
\hline $\begin{array}{c}\text { Conc. of leaf } \\
\text { extract }(\mathrm{ml})\end{array}$ & \multicolumn{4}{c}{ Radial mycelial growth $(\mathrm{cm})$ after different time intervals $(\mathrm{h})$} \\
\cline { 2 - 4 } & 21 & 24 & 27 & 30 \\
\hline 0 (Control) & 1.70 & 2.00 & 2.30 & 3.20 \\
0.5 & 1.20 & 1.50 & 1.90 & 2.60 \\
1.0 & 0.20 & 0.40 & 0.60 & 1.10 \\
2.0 & 0.10 & 0.12 & 0.15 & 0.30 \\
4.0 & 0.05 & 0.10 & 0.12 & 0.15 \\
\hline
\end{tabular}

After mutation in $N$. crassa (Ema) conidia with leaf extract of C. aurantifolia, the mutants were classified into 6 morphological mutant groups (Table 2). They were albino (al 243), vigorous (vg 117), fluffy (fl 220), colonial (cl 232), conidial band (con.band 171) and dirty (dir 83). Among the 48 morphological mutants, the conidial band mutant was the most prevalent $(27 \%)$ while colonial represented the lowest $(4 \%)$ type of mutants. The plant leaf extract induced mutants were then used for estimation of soluble protein.

Table 2. Classification and nomenclature of induced mutants of Neurospora crassa by Citrus aurantifolia leaf extract.

\begin{tabular}{lllcc}
\hline Groups & $\begin{array}{l}\text { Name of the } \\
\text { mutants }\end{array}$ & \multicolumn{1}{c}{ Characteristics } & $\begin{array}{c}\text { No. of } \\
\text { mutants }\end{array}$ & $\begin{array}{c}\text { Frequency } \\
(\%)\end{array}$ \\
\hline A & Albino & Both condia and mycelia are colourless & 9 & 18.75 \\
B & Vigorous & Profuse conidial growth touches the plug & 8 & 16.66 \\
C & Fluffy & Profuge mycelial growth & 11 & 22.92 \\
D & Colonial & Dense mycelial growth inside the tube & 2 & 4.17 \\
E & Conidial & Conidia formed a nice band at the tip of the & 13 & 27.08 \\
& band & growth & & 10.42 \\
F & Dirty & Conidial lump scattered throughout the & 5 & \\
& & body of the culture tube & &
\end{tabular}

It was found that mutant con.band 232 contains highest soluble protein (192.86 $\mu \mathrm{g} / \mathrm{ml})$ whereas wild $N$. crassa (Ema) contains fewer amount $(182.14 \mu \mathrm{g} / \mathrm{ml})$. Besides, vg $117(186.43 \mu \mathrm{g} / \mathrm{ml})$, and $\mathrm{cl} 171(188.57 \mu \mathrm{g} / \mathrm{ml})$ also contain more amount of soluble protein in comparison with the wild (Table 3). These findings revealed that mutation has no considerable effect for the production of soluble protein. On the other hand, the soluble protein content was remarkably decreased in case of the mutant al $243(94.28 \mu \mathrm{g} / \mathrm{ml})$, which was about $50 \%$ less than the control. This indicates that the leaf extract not only 
effect colony morphology but possesses profound effect on growth and metabolism of the fungus. The early reported study(11) also indicated that different mutant showed variation in their protein content in comparison with the wild type.

Table 3. Soluble protein of wild and mutants of Neurospora crassa.

\begin{tabular}{ccc}
\hline $\begin{array}{c}\text { Serial } \\
\text { No. }\end{array}$ & $\begin{array}{c}\text { Name and No. of wild } \\
\text { and mutants }\end{array}$ & $\begin{array}{c}\text { Amount of soluble protein } \\
(\mu \mathrm{g} / \mathrm{ml})\end{array}$ \\
\hline 1 & Ema & 182.14 \\
2 & al 243 & 94.28 \\
3 & vg 117 & 186.43 \\
4 & fl 220 & 162.14 \\
5 & con. band 171 & 192.86 \\
6 & cl 232 & 188.57 \\
7 & dir 83 & 154.28 \\
\hline
\end{tabular}

It is reported that Neurospora has been used in several human societes; either as a food or in processing foods and beverages. It is a major constituent of onchom, a highly nutritious soybean-based presscake produced for human consumption as a cottage industry in West Java.(12) It is also used in preparing oriental foods such as Koji. (13) So, $N$. crassa and its mutants can also be used in processing valuable foods and beverages in Bangladesh.

\section{References}

1. Perkins DD and RH Davis 2000. Evidence for safety of Neurospora species for academic and commercial uses. Applied and Environmental Microbiology 66(12): 5107-5109.

2. Lodish H, A Berk, P Matsudaira, CA Kaiser, M Krieger, MP Scott, SL Zipurksy and J Darnell 2004. Molecular Cell Biology, 5th ed. WH Freeman and Company, New York.

3. Voet D and JG Voet 2004. Biochemistry Vol 13 rd ed. Wiley, Hoboken, NJ.

4. Haque $\mathrm{T}$ and $\mathrm{S}$ Shamsi 1996. Activity of certain plant extract against jute stem rot fungus Macrophomina phaseolina. Dhaka Univ. J. Biol. Sci. 5(1): 103 -104.

5. Haque T and S Shamsi 1997. Activity of some plant extracts on growth of sheath rot pathogen Sarocladium oryzae (Sawada). W. Rames and D. Hawksa. J. Asiat. Soc. Bangladesh, Sci. 231: 153- 155.

6. Mozmader TIMA, N Yesmin and A Jabbar 2000. Induction of mutation in Neurospora crassa with aqueous extract of garlic (Allium sativum L.) and genetical and chromatographic studies of some selected mutants. Dhaka Univ. J. Biol. Sci. 9(2): 143 -150.

7. Mozmader TIMA, US Keya and T Haque 2002. Induction of mutation in Neurospora crassa with aqueous, petroleum ether and chloroform extracts of Neem (Azadirachta Indica A. Juss) leaves. Dhaka Univ. J. Biol. Sci. 11(2): 167 -173.

8. Vogel HJ 1956. A convenient growth medium for Neurospora crassa. Microbial Genetics Bull. 13: 42- 43. 
9. Lowry O H, NJ Rosebrough, AI Farr and RJ Randall 1951. Protein measurement with the folin phenol reagent. J. Bio. Chem. 193: 265

10. Ghani A 2003. Medicinal plants of Bangladesh 2nd ed. Asiatic Society of Bangladesh, Dhaka-1000, Bangladesh.

11. Rahim T. 2001. Genetical and biochemical investigations and protoplast fusion of anthranilic acid mutants of Neurospora crassa. Ph.D. thesis. Department of Botany, University of Dhaka, Dhaka, Bangladesh.

12. Matsuo M 1997. Preparation and components of okara-ontjom, a traditional Indonesian fermented food. J. Jpn. Soc. Food Sci. Tech. 44: 632-639.

13. Moreau-Froment M 1956. Les Neurospora. Bull. Soc. Bot. France. 103: 678-738.

(Manuscript received on 8 December, 2009; revised on 28 February, 2010) 